\title{
DAMPAK RASIO KEUANGAN DAN GOOD CORPORATE GOVERNANCE TERHADAP NILAI PERUSAHAAN
}

\author{
Velecia Apriana dan Herman Ruslim \\ Program Studi Manajemen Fakultas Ekonomi dan Bisnis Universitas Tarumanagara, Jakarta \\ Email: veleciaa4@gmail.com
}

\begin{abstract}
This study aims to examine the effect of financial ratios (liquidity, profitability, and free cash flow) and good corporate governance (independent board of commissioners) on firm value by using time-series data of property and real estate companies listed in Indonesia Stock Exchange in the period of 2015-2019. The samples of this study were 33 firms (165 observations). The method used in this study is multiple panel data regression analysis using E-Views 10.0 software. Firm value is measured by Tobin's $Q$, liquidity is measured by current ratio, profitability is measured by return on equity, free cash flow is measured by free cash flow ratio, and independent board of commissioners is measured by independent commissioners ratio. The results show that liquidity and free cash flow significantly influence firm value, but profitability and independent board of commissioners do not have any significant influence on firm value.
\end{abstract}

Keywords: Liquidity, Profitability, Free Cash Flow, Independent Board of Commissioners, Firm Value.

Abstrak: Penelitian ini bertujuan untuk menguji pengaruh rasio keuangan (liquidity, profitability, dan free cash flow) dan good corporate governance (independent board of commissioners) terhadap firm value dengan menggunakan data time-series pada perusahaan property dan real estate yang terdaftar di BEI periode 2015-2019. Sampel pada penelitian ini berjumlah 33 perusahaan (165 observasi). Metode yang digunakan dalam penelitian ini adalah panel data regression analysis menggunakan software E-Views 10.0. Firm Value diukur menggunakan Tobin's Q, liquidity diukur menggunakan current ratio, profitability diukur menggunakan return on equity, free cash flow diukur menggunakan free cash flow ratio, dan independent board of commissioners diukur menggunakan independent commissioners ratio. Hasil penelitian menunjukkan bahwa liquidity dan free cash flow berpengaruh signifikan terhadap nilai perusahaan, tetapi profitability dan independent board of commissioners tidak berpengaruh signifikan terhadap firm value.

Kata Kunci: Liquidity, Profitability, Free Cash Flow, Independent Board of Commissioners, Firm Value.

\section{LATAR BELAKANG}

Manajemen keuangan menekankan bahwa tujuan utama perusahaan adalah untuk meningkatkan nilai perusahaan (firm value) (Gitman \& Zutter, 2015, h. 70). Nilai perusahaan ditetapkan sebagai tujuan utama karena menunjukkan tingkat kesejahteraan pemegang saham dan kepercayaan masyarakat terhadap perusahaan.

Penelitian Hertina, Hidayat, dan Mustika (2019) menunjukkan bahwa rata-rata nilai perusahaan sektor property dan real estate yang diukur dengan menggunakan indikator Price to Book Value mengalami fluktuasi yang cenderung menurun pada tahun 2014-2017. Data 
Bursa Efek Indonesia (2019) juga menunjukkan terjadi fluktuasi return sektor property dan real estate dari tahun 2009 hingga 2019 hingga mencapai negatif 9,64\% pada akhir tahun 2018.

Berbagai penelitian telah dilakukan untuk mengidentifikasi faktor-faktor yang dapat memprediksi nilai perusahaan, tetapi hasil penelitian tersebut belum konsisten, termasuk hasil penelitian terbaru yang dilakukan dalam rentang waktu lima tahun terakhir (Hidayat, 2019).

Sukmawardini dan Ardiansari (2018) melalui penelitiannya menunjukkan bahwa liquidity memiliki pengaruh yang negatif dan signifikan terhadap nilai perusahaan karena dalam kegiatan operasionalnya ada kas yang menganggur atau aset yang tidak digunakan oleh manajer perusahaan sehingga semakin tinggi likuiditas dapat menurunkan nilai perusahaan. Hasil penelitian Suparno dan Pitoyo, D. (2016) menunjukkan bahwa profitability memiliki pengaruh yang positif dan signifikan terhadap nilai perusahaan sehingga kemampuan perusahaan dalam menghasilkan laba dapat meningkatkan nilai perusahaan tersebut. Penelitian Dewi, Sari, Budiasih, dan Suprasto (2019) menunjukkan bahwa free cash flow memiliki pengaruh yang positif dan signifikan terhadap nilai perusahaan dan akan memberikan sinyal yang positif terhadap investor mengenai nilai perusahaan di masa yang akan datang. Handayani et al. (2020) melalui penelitiannya menunjukkan bahwa independent board of commissioners memiliki pengaruh yang positif dan signifikan terhadap nilai perusahaan karena dapat mengurangin agency conflict dengan adanya pengawasan dan transparansi.

Dari berbagai data di atas, maka penelitian ini akan menganalisis beberapa faktor yang dapat mempengaruhi nilai perusahaan yang berada dalam industri property dan real estate pada periode 2015-2019, yaitu liquidity, profitability, free cash flow, dan independent board of commissioners.

\section{KAJIAN TEORI}

\section{Value of the Firm}

Berdasarkan Keown et al. (2017, h. 163), nilai perusahaan juga tercermin dari harga pasar saham perusahaan. Nilai suatu perusahaan akan semakin meningkat jika harga pasar saham perusahaan semakin meningkat. Selain itu, menurut Damodaran (2017, h. 93) analisis penilaian atau valuation konvensional juga dapat dilakukan baik dengan merumuskan besar nilai yang diharapkan, besarnya pendapatan perusahaan maupun kemungkinan arus kas perusahaan.

Kantor Jasa Penilai Publik (KJPP) wajib memenuhi ketentuan Standar Penilaian Indonesia (SPI) dalam melakukan penilaian maupun revaluasi yang dalam proses pelaksanaannya terdapat tiga pendekatan (Musthafa, Triyuwono, \& Adib, 2020).

Berdasarkan KEPI dan SPI (2018), terdapat tiga pendekatan yang dapat digunakan pada saat melakukan penilaian perusahaan, yaitu pendekatan pasar (market approach), pendekatan pendapatan (income approach), dan pendekatan aset (asset approach). Penelitian ini melakukan penilaian perusahaan dengan menggunakan pendekatan pasar (market approach) menggunakan data pada perusahaan yang berada pada industri property dan real estate, menggunakan metode pembanding untuk perusahaan yang telah terdaftar pada Bursa Efek Indonesia, dan metode pembanding untuk berbagai transaksi perusahaan sebelumnya yang telah terjadi pada periode 2015 hingga 2019.

2. Signaling Theory

Spence (1973) memperkenalkan signaling theory yang menyatakan bahwa manajer akan memberikan sinyal kepada pemegang saham mengenai kondisi perusahaan. Melalui signaling theory dapat disimpulkan bahwa peningkatan liquidity akan memberikan pengaruh negatif terhadap nilai perusahaan karena tingginya likuiditas aset seperti kas perusahaan, menunjukkan sinyal bahwa perusahaan tersebut memiliki kas yang menganggur. Selain itu, semakin tinggi profitability perusahaan maka semakin tinggi nilai perusahaan karena dengan tingkat 
keuntungan yang tinggi, perusahaan dapat membagikan dividen yang tinggi sehingga memberikan sinyal kesejahteraan pemegang saham yang akan semakin meningkat.

3. Agency Theory

Agency theory diperkenalkan oleh Jensen \& Meckling (1976) yang menjelaskan hubungan keagenan melalui teori keagenan perusahaan yaitu sebagai kumpulan kontrak kerjasama (nexus of contract) antara pihak pemilik perusahaan atau pemegang saham (principal) dan pihak manajer (agent). Free cash flow perusahaan yang tinggi akan meningkatkan nilai perusahaan karena manajer dapat menggunakan aliran kas bebas untuk keputusan investasi dan pembayaran dividen kepada pemegang saham yang dapat meningkatkan nilai perusahaan tersebut. Melalui agency theory juga dapat disimpulkan bahwa semakin tinggi independent board of commissioners yang ada pada suatu perusahaan maka semakin tinggi nilai perusahaan tersebut karena dengan adanya komisaris independen, maka semakin ketat pengawasan terhadap berbagai pihak yang ada di suatu perusahaan seperti manajer dan direktur sehingga mencegah terjadinya kecurangan.

Liquidity memiliki pengaruh yang negatif dan signifikan terhadap nilai perusahaan. Berdasarkan hasil penelitian Fajaria dan Isnalita (2018) menunjukkan bahwa likuiditas yang tinggi menunjukkan jumlah kas menganggur atau idle cash yang semakin tinggi. Hal ini dapat memberikan sinyal kepada pemegang saham bahwa perusahaan tidak memiliki kinerja yang baik dalam pengelolaan likuiditas aset sehingga dapat berdampak pada penurunan nilai perusahaan. Sukmawardini dan Ardiansari (2018) dan Febriyanto (2018) melalui penelitiannya menunjukkan bahwa liquidity memiliki pengaruh yang negatif dan signifikan terhadap firm value. Sehingga peningkatan liquidity akan menyebabkan penurunan pada firm value karena liquidity yang tinggi menunjukkan adanya kas menganggur dalam jumlah yang besar sehingga dapat menurunkan nilai perusahaan.

Profitability memiliki pengaruh yang positif dan signifikan terhadap firm value (Tahu dan Susilo, 2017). Tingginya profitability menunjukkan bahwa perusahaan mampu menghasilkan laba bersih yang tinggi sehingga pembagian dividend yang diterima oleh pemegang saham akan meningkat. Hal ini seuai dengan signaling theory dimana pembagian dividend yang meningkat akibat profitability perusahaan yang tinggi menjadi sinyal bagi pemegang saham mengenai nilai perusahaan saat ini. Oktariana (2018); Husna dan Satria (2019); Fajaria dan Isnalita (2018) melalui penelitiannya menunjukkan bahwa profitability memberikan pengaruh yang positif dan signifikan terhadap firm value. Sehingga semakin tinggi profitability maka nilai perusahaan akan semakin meningkat.

Free cash flow memberikan hubungan yang positif dan signifikan terhadap firm value (Dewi et al., 2019). Tingginya free cash flow menunjukkan besarnya arus kas yang tersedia untuk kreditur maupun pemegang saham. Pihak manajer sebagai agent memiliki peran penting dalam menentukan penggunaan free cash flow agar dapat meningkatkan nilai perusahaan. Berdasarkan agency theory, semakin besar free cash flow yang digunakan untuk membayar dividend kepada pemegang saham, maka semakin besar nilai perusahaan. Penelitian Mansourlakoraj dan Sepasi (2015); Le (2017); Chosiah, Purwanto, dan Ermawati (2019) menunjukkan bahwa free cash flow memberikan pengaruh yang positif dan signifikan terhadap firm value. Sehingga semakin tinggi free cash flow maka nilai perusahaan akan semakin tinggi.

Independent board of commissioners memberikan pengaruh yang positif dan signifikan terhadap firm value (Dewi, Rasmini, dan Ratnadi, 2019). Banyaknya jumlah komisaris independen pada suatu perusahaan akan memperkuat pengawasan dan mencegah terjadinya agency conflict dan agency cost perusahaan. Sehingga berdasakan agency theory, semakin banyak komisaris independen perusahaan maka dapat meningkatkan nilai perusahaan tersebut. 
Maryanti dan Fithri (2017); Setiadi et al. (2017); Utomo et al.(2018); Handayani et al. (2020) berdasarkan penelitiannya menunjukkan bahwa independent board of commissioners memberikan pengaruh yang positif dan signifikan terhadap firm value. Sehingga semakin besar komposisi komisaris independen maka semakin besar nilai perusahaan tersebut.

Berdasarkan kerangka pemikiran tersebut, maka peningkatan liquidity akan menurunkan firm value, peningkatan profitability akan meningkatkan firm value, peningkatan free cash flow akan meningkatkan firm value, dan peningkatan independent board of commissioners akan meningkatkan firm value, sehingga model kerangka pemikiran pada penelitian ini adalah sebagai berikut:

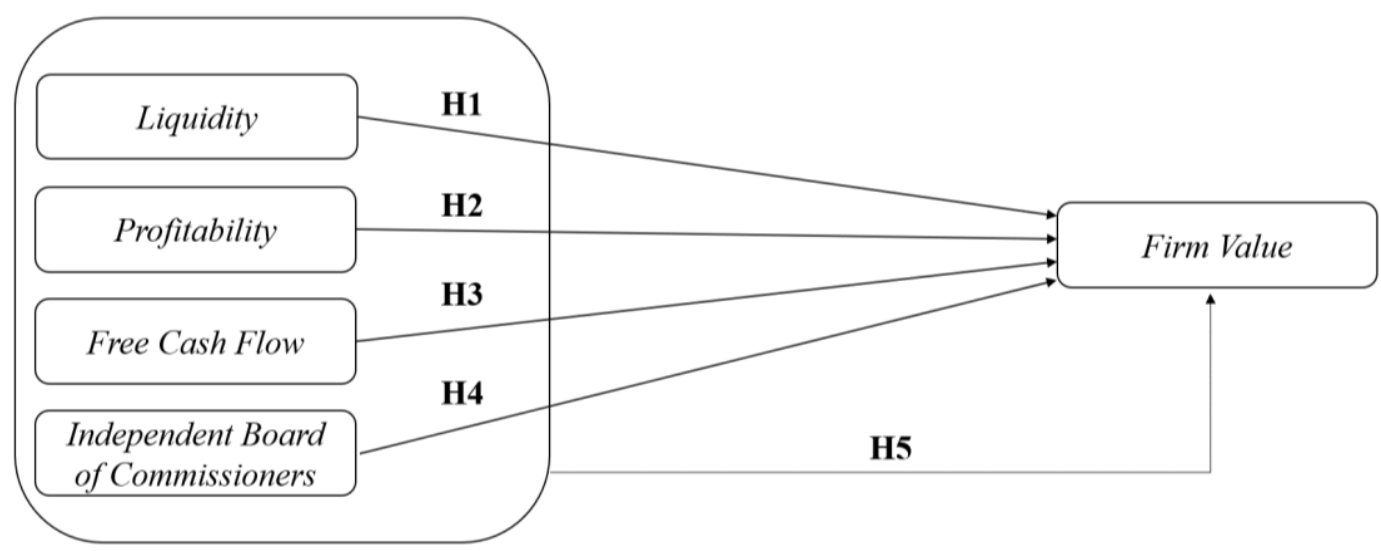

Dengan demikian, berdasarkan kerangka pemikiran, hipotesis pada penelitian ini dirumuskan sebagai berikut:

1. Hipotesis 1: H1: Liquidity dapat mempengaruhi Firm Value secara negatif.

2. Hipotesis 2: H2: Profitability dapat mempengaruhi Firm Value secara positif.

3. Hipotesis 3: H3: Free Cash Flow dapat mempengaruhi Firm Value secara positif.

4. Hipotesis 4: H4: Independent Board of Commissioners dapat mempengaruhi Firm Value secara positif.

5. Hipotesis 5: H5: Liquidity, Profitability, Free Cash Flow, dan Independent Board of Commissioners secara bersama-sama (simultan) mempengaruhi Firm Value.

\section{METODOLOGI}

Unit subyek yang akan diteliti dalam penelitian ini adalah perusahaan sektor property dan real estate yang terdaftar di Bursa Efek Indonesia pada periode 2015-2019. Penelitian ini menggunakan kriteria purposive sampling, yaitu Perusahaan property dan real estate di Indonesia yang telah melakukan Initial Public Offering (IPO) sebelum tahun 2015, Perusahaan yang beroperasi pada sektor industri property dan real estate pada periode 2015-2019 dan tidak melakukan perpindahan sektor pada periode tersebut, laporan keuangan diterbitkan tanggal 31 Desember setiap periode dan telah diaudit dalam mata uang Rupiah, dan perusahaaan tidak tergolong sebagai saham tidur yang diperdagangkan dengan harga Rp 50 per lembar selama periode 2015-2019. Setelah peneliti menetapkan kriteria purposive sampling, maka subyek penelitian yang memenuhi kriteria purposive sampling adalah sebesar 33 perusahaan. Laporan keuangan dan laporan tahunan yang digunakan dalam pengumpulan data pada penelitian ini diperoleh dengan mengunduh situs resmi Bursa Efek Indonesia dan situs perusahaan yang menjadi sampel penelitian. 
Obyek penelitian yang digunakan dalam penelitian ini terdiri dari satu variabel dependen yaitu firm value dan empat variabel independen yaitu liquidity, profitability, free cash flow, dan independent board of commissioners pada perusahaan sektor industri property dan real estate yang terdaftar secara resmi di Bursa Efek Indonesia (BEI) periode 2015-2019 sebagai subyek penelitian. Berikut merupakan operasionalisasi variabel penelitian:

1. Firm Value

Tobin's $Q=\frac{\text { Market Value Equity }+ \text { Total Liabilities }}{\text { Total Assets }}$

2. Liquidity

Current Ratio $=\frac{\text { Current Assets }}{\text { Current Liabilities }}$

3. Profitability

Return on Equity $=\frac{\text { Earning After } \text { Tax }}{\text { Total Equity }}$

4. Free Cash Flow

Free Cash Flow Ratio $=\frac{\left(\begin{array}{c}\text { Operating Net Income }+ \text { Depreciation Expenses }- \\ \text { Corporate Income Tax-Interest Expenses- } \\ \text { Cash Dividends }\end{array}\right)}{\text { Total Assets }}$

5. Independent Board of Commissioners

Total Assets

Independent Commissioners Ratio $=\frac{\text { Total Independent Commissioners }}{\text { Total Board of Commissioners }}$

\section{HASIL ANALISIS DATA}

\section{Uji Statistik Deskriptif}

Variabel Tobin's Q memiliki nilai rata-rata (mean) sebesar 0.930647, nilai tengah (median) sebesar 0.926640, dan standar deviasi sebesar 0.373370. Nilai maksimum sebesar 1.985298 dan nilai minimum sebesar 0.122833. Variabel Current Ratio memiliki nilai rata-rata (mean) sebesar 2.716796, nilai tengah (median) sebesar 1.653107, dan standar deviasi sebesar 2.834993. Nilai maksimum sebesar 21.70452 dan nilai minimum sebesar 0.178554 . Variabel Free Cash Flow Ratio memiliki nilai rata-rata (mean) sebesar 0.005364, nilai tengah (median) sebesar 0.006666, dan standar deviasi sebesar 0.058025 . Nilai maksimum sebesar 0.122781 dan nilai minimum sebesar -0.275463. Variabel Independent Board of Commissioners memiliki nilai rata-rata (mean) sebesar 0.361513, nilai tengah (median) sebesar 0.333333 , dan standar deviasi sebesar 0.095149. Nilai maksimum sebesar 0.600000 dan nilai minimum sebesar 0.111111 .

\section{Uji Asumsi Analisis Data}

Uji Chow menunjukkan nilai probabilitas cross-section $\mathrm{F} 0.0000<0.05$, sehingga $\mathrm{H} 0$ ditolak atau Common Effect Model dinilai tidak tepat digunakan untuk mengestimasi data panel. Uji Hausman menunjukkan nilai probabilitas cross-section F $0.0786>0.05$, sehingga H0 tidak ditolak sehingga model yang akan digunakan untuk mengestimasi data panel dalam penelitian ini adalah Random Effect Model. Uji Lagrange menunjukkan nilai probabilitas crosssection Breusch-Pagan $0.0000<0.05$, sehingga H0 ditolak dan model yang akan digunakan untuk mengestimasi data panel penelitian ini adalah Random Effect Model.

\section{Uji Asumsi Klasik}


Uji Normalitas dilakukan untuk mengetahui apakah data yang digunakan pada penelitian terdistribusi secara normal atau tidak terdistribusi secara normal. Nilai probabilitas Jarque-Bera yang diperoleh berdasarkan uji normalitas pada gambar 1 sebesar $0.216864>0.05$. Hal ini menunjukkan bahwa data yang digunakan dalam penelitian ini berada dalam sebaran normal.

Gambar 1. Hasil Uji Normalitas

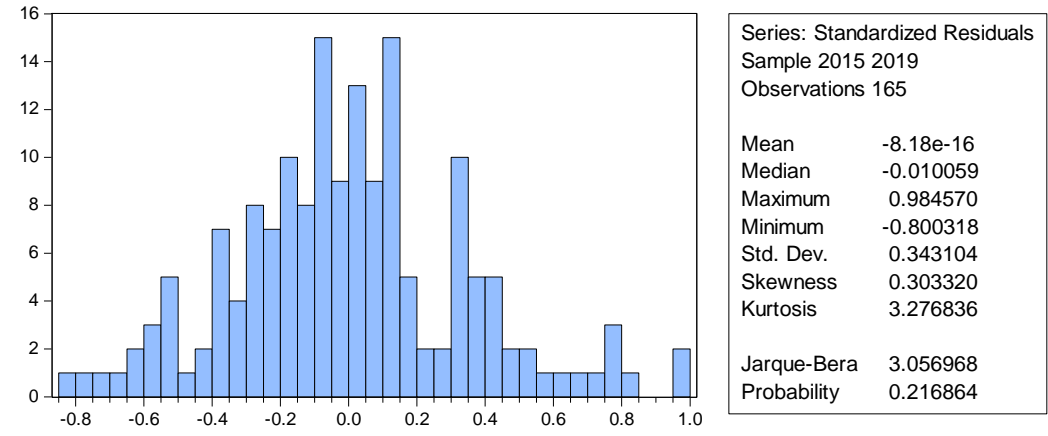

Uji Multikolinearitas dilakukan untuk mengetahui korelasi atau hubungan antara variabel bebas atau variabel independen yang digunakan dalam penelitian. Hasil uji Multikolinearitas yang telah dilakukan pada tabel 1 menunjukkan bahwa koefisien korelasi masing-masing variabel bebas bernilai kurang dari 0.8. Hal ini menunjukkan bahwa variabel-variabel bebas yang digunakan dalam penelitian ini tidak mengalami multikolinearitas.

Tabel 1. Hasil Uji Multikolinearitas

\begin{tabular}{|c|r|r|r|r|}
\hline & \multicolumn{1}{|c|}{ CR } & \multicolumn{1}{c|}{ ROE } & \multicolumn{1}{|c|}{ FCF } & \multicolumn{1}{c|}{ IC } \\
\hline CR & 1.000000 & 0.016811 & -0.059175 & 0.088174 \\
\hline ROE & 0.016811 & 1.000000 & 0.118731 & -0.062162 \\
\hline FCF & -0.059175 & 0.118731 & 1.000000 & -0.106184 \\
\hline IC & 0.088174 & -0.062162 & -0.106184 & 1.000000 \\
\hline
\end{tabular}

\section{Analisis Regresi Berganda}

Berikut merupakan persamaan regresi yang digunakan dalam penelitian ini:

TOBINS_Q $=1.135811-0.028546 \mathrm{CR}+0.072055 \mathrm{ROE}+0.324031 \mathrm{FCF}-0.369443 \mathrm{IC}+\varepsilon_{i, t}$

Tabel 2. Hasil Uji Analisis Regresi Berganda

\begin{tabular}{crrrr}
\hline \hline Variable & Coefficient & Std. Error & t-Statistic & Prob. \\
\hline \hline C & 1.135811 & 0.162861 & 6.974101 & 0.0000 \\
CR & -0.028546 & 0.005275 & -5.411371 & 0.0000 \\
ROE & 0.072055 & 0.056128 & 1.283761 & 0.2011 \\
FCF & 0.324031 & 0.123884 & 2.615599 & 0.0098 \\
IC & -0.369443 & 0.229615 & -1.608967 & 0.1096 \\
\hline \hline
\end{tabular}

Weighted Statistics

\begin{tabular}{lll}
\hline \hline R-squared & $0.078761 \quad$ Mean dependent var 0.278760
\end{tabular}


Adjusted R-

\begin{tabular}{llll} 
squared & 0.055730 & S.D. dependent var & 0.200188 \\
F-statistic & 3.419799 & Durbin-Watson stat & 0.761004 \\
Prob(F-statistic) & 0.010307 & \\
\hline
\end{tabular}

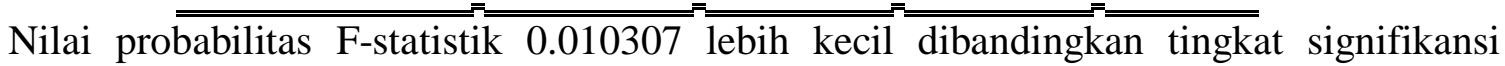
penelitian sebesar 0.05 . Sehingga $\mathrm{H} 0$ ditolak, artinya terdapat pengaruh yang signifikan antara Current Ratio, Return on Equity, Free Cash Flow, dan Independent Commissioners secara bersama-sama terhadap Tobin's Q dengan tingkat keyakinan sebesar 5\%.

Nilai Adjusted R-Squared pada penelitian ini 0.055730 atau $5.57 \%$. Hal ini menunjukkan bahwa kontribusi variabel-variabel independen yang digunakan pada penelitian ini untuk menjelaskan variabel dependen penelitian adalah 5.57\%. Sedangkan, sebesar $94.43 \%$ dapat dijelaskan oleh berbagai variabel lainnnya yang tidak digunakan pada penelitian ini.

\section{DISKUSI}

Hasil penelitian menunjukkan bahwa Liquidity memberikan pengaruh yang negatif dan signifikan, sehingga semakin besar likuiditas suatu perusahaan maka nilai perusahaan akan semakin rendah dan sebaliknya. Hal ini sesuai dengan signaling theory yang menunjukkan bahwa tingginya likuiditas perusahaan memberikan sinyal kepada investor bahwa kondisi nilai perusahaan rendah. Terdapat berbagai penyebab tingginya likuiditas perusahaan, seperti tingginya likuiditas aset yang disebabkan oleh tingginya kas perusahaan yang menunjukkan adanya idle cash atau kas perusahaan yang menganggur. Kas perusahaan yang menganggur dan tidak digunakan dapat mengurangi keuntungan atau cash dividends yang mampu diperoleh investor. Hasil penelitian ini mendukung hasil penelitian yang telah dilakukan oleh Fajaria \& Isnalita (2018), Sukmawardini \& Ardiansari (2018), dan Febriyanto (2018).

Hasil penelitian menunjukkan bahwa Profitability tidak memberikan pengaruh yang signifikan terhadap Firm Value karena perusahaan sektor industri property dan real estate yang lesu pada periode 2015-2019. Hal ini menunjukkan bahwa berdasarkan signaling theory, tingkat keuntungan perusahaan yang tinggi pada periode 2015-2019 tidak dapat digunakan sebagai sinyal bahwa nilai perusahaan berada pada kondisi yang baik karena terdapat berbagai faktor lain yang dapat mempengaruhi nilai suatu perusahaan. Pada tahun 2019 dimana Indeks Harga Saham Gabungan (IHSG) sektor property dan real estate ditutup dengan penurunan tajam di level 6.115,13 pada Agustus 2019 (CNBC, 2019). Berdasarkan data BEI (2019) sektor property dan real estate juga mengalami fluktuasi dalam kemampuan menghasilkan return dan mengalami penurunan yang terendah hingga mencapai negatif 9,64\% pada akhir tahun 2018 . Hasil penelitian ini mendukung penelitian Hapsoro \& Falih (2020) namun tidak sejalan dengan penelitian Tahu \& Susilo (2017), Oktariana (2018), dan Husna \& Satria (2019).

Hasil penelitian menunjukkan bahwa Free Cash Flow memberikan pengaruh yang positif dan signifikan, sehingga semakin besar arus kas bebas suatu perusahaan maka nilai perusahaan akan semakin besar. Free Cash Flow yang tinggi dan digunakan dengan baik oleh pihak manajer perusahaan, sesuai dengan agency theory maka menunjukkan adanya kinerja yang baik oleh pihak manajer perusahaan dalam pengelolaan dana arus kas bebas perusahaan yang tersedia untuk pembayaran kreditur maupun pemegang saham sehingga dapat menghasilkan nilai perusahaan yang tinggi. Free Cash Flow yang menggunakan proksi perbandingan arus kas bebas terhadap total aset juga menunjukkan bahwa perusahaan memiliki arus kas aktivitas operasional yang baik yang berpengaruh terhadap nilai perusahaan yang semakin baik. Hasil penelitian ini mendukung hasil penelitian yang telah dilakukan oleh Dewi et al. (2019); Mansourlakoraj \& Sepasi (2015); Le (2017); Chosiah, Purwanto, \& Ernawati (2019). 
Hasil penelitian menunjukkan bahwa Independent Board of Commissioners tidak memberikan pengaruh yang signifikan terhadap nilai perusahaan. Karena adanya dewan komisaris independen yang tidak objektif dalam pelaksanaan tugasnya sehingga tidak berpengaruh terhadap nilai perusahaan. Berdasarkan agency theory, komisaris independen sebagai penghubung antara pihak pemilik perusahaan (principal) dan manajer (agent) tidak melaksanakan tugasnya dengan baik dalam menjembatani pihak principal dan agent sehingga tidak memberikan pengaruh terhadap nilai perusahaan. Hasil penelitian ini mendukung hasil penelitian yang telah dilakukan oleh Rusli, Nainggolan, \& Pangestu (2020), namun hasil penelitian ini tidak sejalan dengan hasil penelitian yang dilakukan oleh Dewi, Rasmini, \& Ratnadi (2019), Utomo et al.(2018), Handayani et al. (2020).

Hasil pengujian uji statistik-F atau uji simultan menunjukkan nilai probabilitas sebesar 0.010307. Nilai probabilitas lebih kecil dibandingkan dengan tingkat signifikansi yang digunakan pada penelitian ini yaitu 0.05. Sehingga kesimpulan yang dapat diambil dari penelitian ini adalah Liquidity, Profitability, Free Cash Flow, dan Independent Board of Commissioners secara bersama-sama memiliki pengaruh terhadap Firm Value perusahaan property dan real estate yang terdaftar yang terdaftar di BEI periode 2015-2019.

\section{PENUTUP}

Berdasarkan uji analisis data, maka hasil penelitian yang diperoleh adalah firm value perusahaan property dan real estate yang terdaftar di Bursa Efek Indonesia periode 2015-2019 dapat dipengaruhi secara signifikan oleh liquidity dan free cash flow sedangkan profitability dan independent board of commissioners tidak memiliki pengaruh yang signifikan terhadap firm value. Selain itu, liquidity, profitability, free cash flow, dan independent board of commissioners secara bersama-sama memiliki pengaruh terhadap firm value. Pada penelitian ini, variabel liquidity diukur menggunakan current ratio, profitability diukur menggunakan return on equity, free cash flow diukur menggunakan free cash flow ratio, independent board of commissioners diukur menggunakan independent commissioners ratio, dan firm value diukur menggunakan Tobin's Q.

Keterbatasan pada penelitian ini adalah penelitian ini hanya menggunakan populasi yang berupa perusahaan sektor industri property dan real estate yang terdaftar di Bursa Efek Indonesia secara berturut-turut pada periode 2015-2019 tanpa menggunakan perusahaan dengan saham yang tidur, koefisien determinasi $\left(\mathrm{R}^{2}\right)$ penelitian ini adalah sebesar $5.57 \%$ sehingga sisanya $94.43 \%$ dapat dijelaskan oleh berbagai faktor dan variabel independen lain yang tidak digunakan pada penelitian ini, dan penelitian ini hanya menggunakan satu proksi sebagai indikator pengukuran bagi masing-masing variabel independen dan variabel dependen. Dengan adanya berbagai keterbatasan penelitian, maka saran bagi penelitian serupa adalah menguji berbagai kemungkinan variabel independen lain yang mampu mempengaruhi firm value, menggunakan proksi lain untuk mengukur variabel independen dan dependen, dan menambah jumlah periode penelitian.

\section{DAFTAR PUSTAKA}

Bursa Efek Indonesia. (2019). IDX Stock Index, available from https://www.idx.co.id/media/8218/idx-stock-index-handbook-_-v10-_-desember2019.pdf, (accessed September $4^{\text {th }}$, 2020). 
Chosiah, C., Purwanto, B., \& Ermawati, W. J. (2019). Dividend Policy, Investment Opportunity Set, Free Cash Flow, and Company Performance: Indonesian's Agricultural Sector. Jurnal Keuangan dan Perbankan, 22(3), 403-417.

CNBC. 2019. "Properti Lesu, Siapa Emiten Properti Paling Menguntungkan?". https://www.cnbcindonesia.com/market/20190806130810-17-90153/properti-lesusiapa-emiten-properti-paling-menguntungkan, diakses pada tanggal 15 Desember 2020.

Damodaran, A. (2017). Narrative and Numbers The Value of Studies in Business, New York: Columbia University Press.

Dewi, I. A. M. C., Sari, M. M. R., Budiasih, I. G. A. N., \& Suprasto, H. B. (2019). Free Cash

Flow Effect towards Firm Value. International Research Journal of Management, IT \& Social Sciences, 6(3), 108-116.

Dewi, K. R. C., Rasmini, N. K., \& Ratnadi, N. M. D. (2019). The Effect of Independent Board of Commissioners, Institutional Ownership, and Managerial Ownership in Firm Values with Environemental Disclosure as Moderating Variable. International Journal of Sciences: Basic and Applied Research, 48(2), 53-67.

Fajaria, A, Z. \& Isnalita. (2018). The Effect of Profitability, Liquidity, Leverage and Firm Grotwh of Firm Value with Its Dividend Policy as A Moderating Variable. International Journal of Managerial Studies and Research, 6(10), 55-69.

Febriyanto, F., C. (2018). The Effect of Leverage, Sales Growth and Liquidity to the Firm Value of Real Estate and Property Sector in Indonesia Stock Exchange. Economic and Accounting Journal, 1(3), 198-205.

Gitman, L. J. \& Zutter, C. J. (2015). Principles of Managerial Finance. England: Pearson Education Limited.

Hapsoro, D. \& Falih, Z. N. (2020). The Effect of Firm Size, Profitavility, and Liquidity on the Firm Value Moderated by Carbon Emission Disclosure. Journal of Accounting an Investment, 21(2), 240-257.

Handayani, B. D., Rohman, A., Chariri, A., \& Pamungkas, I. D. (2020). Corporate Financial Perfomance on Corporate Governance Mechanism and Corporate Value: Evidence from Indonesia. Montenegrin Journal of Economics, 16(3), 161-171.

Hertina, D., Hidayat, M. B. H., \& Mustika, D. (2019). Ukuran Perusahaan, Kebijakan Hutang dan Profitabilitas Pengaruhnya Terhadap Nilai Perusahaan. Jurnal Ecodemica, 3(1), 1-10.

Hidayat, W. W. (2019). Pengaruh Ukuran Perusahaan, Return on Equity dan Leverage terhadap Nilai Perusahaan pada Perusahaan Manufaktur di Indonesia. Forum Ekonomi, 21(1), 6775.

Husna, A., \& Satria, I. (2019). Effects of Return on Asset, Debt to Asset Ratio, Current Ratio, Firm Size, and Dividend Payout Ratio on Firm Value. International Journal of Economics and Financial Issues, 9(5), 50-54.

Jensen, M. C. \& Meckling, W. H. (1976). Theory of the Firm: Managerial Behavior, Agency Costs, and Ownership Structure. Journal of Financial Economics, 3, 305-360.

Keown, A. J., Martin, J. D., \& Petty, J. W. (2017). Foundation of Finance, Harlow: Pearson Education Limited.

KEPI dan SPI. (2018). Kode Etik Penilai Indonesia dan Standar Penilaian Indonesia, Edisi VII, penerbit MAPPI dan KSPI. 
Le, L. H. (2017). Free Cash Flow and Firm Performance: Evidence from Sectoral Levels for Vietnamese Listed Firms. International Journal of Advanced Engineering, Management and Science, 3(4), 296-300.

Mansourlakoraj, R. \& Sepasi, S. (2015). Free Cash Flow, Capital Structure and the Value of Listed Companies in Tehran Stock Exhange. International Journal of Management, Accounting and Economics, 2(2), 144-148.

Maryanti, E. \& Fithri, W. N. (2017). Corporate Social Responsibility, Good Corporate Governance, Kinerja Lingkungan terhadap Kinerja Keuangan dan Pengaruhnya pada Nilai Perusahaan. Journal of Accounting Science, 1(1), 21-37.

Musthafa, T. F., Triyuwono, I., \& Adib, N. (2020). Application of Asset Revaluation by the Public Assesment Office: A Reflection of Sharia Accounting, Shari'ah Enterprise Theory. International journal of Economics, Business and Accounting Research, 4(3), $16-26$.

Oktariana, D.(2018). The Analysis of Firm Value in Indonesia Property and Real Estate Companies. International Journal of Research Science \& Management, 5(9), 85-92.

Rusli, Y. M., Nainggolan, P., \& Pangestu, J. C. (2020). Pengaruh Independent Board of Commissioners, Institutional Ownership, dan Audit Committee terhadap Firm Value. Journal of Business and Applied Management, 13(1), 49-64.

Setiadi, I., Rahmawati, Suhardjanto, D., \& Djuminah. (2017). Board Independence, Environmental Disclosure, and Firm Value. Review of Integrative Business and Economics Research, 6(4), 409-417.

Sukmawardini, D. \& Ardiansari, A. (2018). The Influence of Institutional Ownership, Profitability, Liquidity, Dividend Policy, Debt Policy on Firm Value. Management Analysis Journal, 7(2), 212-222.

Suparno \& Pitoyo, D. (2016). Determinant Factor of Firm's Value on Manufacturing Company in Indonesian Stock Exchange. Advances in Economics, Business and Management Research, 15, 138-147.

Spence, M. (1973). Job Market Signaling. The Quarterly Journal of Economics, 87(3), 355374.

Sukmawardini, D. \& Ardiansari, A. (2018). The Influence of Institutional Ownership, Profitability, Liquidity, Dividend Policy, Debt Policy on Firm Value. Management Analysis Journal, 7(2), 212-222.

Tahu, G. P. \& Susilo, D. D. B. (2017). Effect of Liquidity, Leverage and profitability to the Firm Value (Dividend Policy as Moderting Variable) in Manufacturing Company of Indonesia Stock Echange. Research Journal of Finance and Accounting, 8(18), 89-98.

Utomo, M. N., Wahyudi, S., Muharam, H., \& Sianturi, J. A. T. P. (2018). Commissioner Board Monitoring to Create Firm Performance through Environmentally Friendly Management. Journal of Environmental Management and Tourism, 9(3), 659-676. 